\title{
PHYSIOLOGICAL AND HISTOLOGICAL RESPONSES OF GIMMIZAH COCKERELS TO GNRH INJECTION
}

\author{
Marwa Sh. Abdo ${ }^{1}$, Nafisa A. Abd El-Azeem ${ }^{2}$ and Reham A.M. Ali ${ }^{3}$ \\ ${ }^{1}$ Dept. of Poultry Production, Fac. of Agric., Ain Shams Univ., Shoubra El-Kheima, Cairo, Egypt. \\ ${ }^{2}$ Dept. of Animal Production, National Research Centre, Dokki, Cairo, Egypt. \\ ${ }^{3}$ Dept. of Animal Production, Fac. of Agric. Natural Resources, Aswan Univ., Egypt.
}

(Received 19/1/2021, accepted 23/3/2021)

\section{SUMMARY}

\begin{abstract}
$\mathrm{T}$ his study was conducted to study the neuroendocrine control of spermatogenesis of Gimmizah Cocks. A total of 300 Gimmizah cockerels aged 5 weeks were selected according to their configuration. Birds were individually weighted and then randomly distributed into 4 experimental groups with 75 males of each. The first group of cockerels (T1) was injected with saline solution for the whole period $(6-14$ wk.) and was considered as a control group. The other 3 groups were injected with a synthetic (Receptal) gonadotropic releasing hormone (GnRH) during the periods from 6 -10 (T2), 8-12 (T3) and 10-14 (T4) weeks of age for the second, third, and fourth groups, respectively. The cockerels of the treated groups were divided into two subgroups the first one (R1) injected with $0.1 \mathrm{ml}$ Receptal / $\mathrm{kg}$ of body weight, while the second (R2) injected with $0.2 \mathrm{ml}$ Receptal / $\mathrm{kg}$ of body weight. Data obtained illustrated that at 12 weeks of age, the plasma level of LH, FSH and testosterone were insignificant. LH and FSH values of T2 group at 14 weeks of age were lower than that recorded for the other treated or control groups. At 16 weeks of age, the plasma concentrations of all hormones were comparable to those obtained at 14 weeks of age. Semen quality traits were significantly improved by injecting GnRH regardless the injected dose. These results suggested that the precocious puberty in Gimmizah males could be achieved by GnRH injection starting from 8 or 10 weeks of age as a result of increasing the spermatogenic activity.
\end{abstract}

Keywords: Gimmizah males, GnRH, Precocious puberty and semen quality.

\section{INTRODUCTION}

Gimmizah is a new local Egyptian improved auto-sex strain developed from a cross between Dokki ${ }_{4}$ (D4) males and White Plymouth Rock females (Mahmoud et al., 1982). Testicular activity in mammals and birds is controlled by information from the external environment, and the internal environment which are integrated in the brain to modulate the secretion of gonadotrophin releasing hormone (Sharp and Gow 1983 and Hezarjaribi et al., 2016). Spermatogenesis is a complicated process in which the division of spermatogonial stem cells ultimately yields sperm cells while a population of stem cells is maintained (Thurston and Korn, 2000). This complex phenomenon occurs within the seminiferous epithelium and depends upon the neurosecretory activity of the hypothalamic nuclei, found exterior to the seminiferous tubules within the central nervous system, the anterior pituitary gland and interstitial tissue of the testis, which stimulates the secretion of gonadotrophin-releasing hormones (GnRH) (Katz et al, 1990, Vizcarra et al., 2004, 2010 and 2015 and Hezarjaribi et al., 2016). The GnRH enters blood vessels that connect the hypothalamus with the pituitary gland and stimulate the gonadotropes cell of the anterior pituitary to secrete follicle-stimulating hormone (FSH) and luteinizing hormone ( $\mathrm{LH}$ ). The importance of GnRH in gonads function and reproduction performance, directed the veterinary therapeutic companies to produce a synthetic analogue to the natural one. Although little information are available concerning the role of GnRH injection in testicular activity in the local strains of chickens, the physiological role of $\mathrm{GnRH}$ injection in different mammalian species was studied by many investigators who observed a significant improvement in semen quality and reproduction performance in male rabbits (Marai et al., 1998), increase conception rate and improve fertility in repeat breeding cows (Stevenson et al., 1988) and increase testosterone in breeder bull (Kozdera et al., 1993). 
Little studies were conducted to investigate the effect of GnRH treatment on galliform species, however, the genetic improvements of the modern strain of chickens lead to impaired fertility, late sexual maturity and same reproductive problems associated with the related neuroendocrine axis (Weil et al., 1999, ElNagar, 2009). Therefore, the present study was conducted to further investigate the possible effect of GnRH injection at different ages before sexual maturity on semen quality traits of Gimmizah strain cockerels.

\section{MATERIALS AND METHODS}

The present experiment was conducted at the Poultry Physiology Research Laboratory, Faculty of Agriculture, Ain Shams University during the winter season. The experiment was aimed to study the neuroendocrine control of spermatogenesis of Gimmizah strain chickens.

\section{Experimental design:}

A total of 300 Gimmizah cockerels, five weeks of age, were obtained from EL- Gimmizah Breeding Station, Poultry Improving Unit, Animal Production Research Institute, Agricultural Research Center, Ministry of Agriculture.

Cockerels were individually weighed and randomly distributed into four experimental groups, 75 cocks each. The first group of cockerels (T1) was injected with saline solution for the whole period (6 14 wk.) and was considered as a control group. The other 3 groups were injected with a synthetic gonadotropic releasing hormone $(\mathrm{GnRH})$ (Receptal) during the periods from 6 -10 (T2), 8-12 (T3) and 10-14 (T4) weeks of age for the second, third, and fourth groups, respectively. The cockerels of the treated groups were divided into two subgroups the first one (R1) injected with $0.1 \mathrm{ml} \mathrm{Receptal} / \mathrm{kg}$ of body weight, while the second (R2) injected with $0.2 \mathrm{ml} \mathrm{Receptal} \mathrm{/} \mathrm{kg}$ of body weight.

Receptal is a veterinary therapeutic product produced by Intervet company as ready-to-use injection solution of a synthetic releasing hormone that releases luteinizing hormone (LH), and follicle-stimulating hormone (FSH) from the anterior lobe of the pituitary. Each ml Receptal contains $0.0042 \mathrm{mg}$ buserelin acetate equivalent to $0.004 \mathrm{mg}$ buserelin and, as antimicrobial additive, $10 \mathrm{mg}$ benzyl alcohol.

All chicks were fed ad libitum on commercial diets. A photoperiod of $16 \mathrm{~h}$. light: $8 \mathrm{~h}$. dark was supplied until the end of the experimental period.

\section{Measurements:}

\section{Biochemical Analysis:}

At 12, 14 and16 weeks of age, five cockerels from each subgroup were randomly taken and slaughtered. Blood samples were collected from the jugular vein into heparinized tubes and centrifuged at $6000 \mathrm{rpm}$ for $10 \mathrm{~min}$., plasma samples were stored in a deep freezer at $-20^{\circ} \mathrm{C}$ until hormonal analysis was done.

Plasma level of FSH was measured by using a micro-modification of a specific homologous RIA which comprised standard purified chicken FSH and rabbit antiserum as described by Krishnan et al. (1993). Plasma LH was determined by using rabbit anti-avian LH serum and the double antibody RIA method as reported by Follett et al. (1972). Testosterone concentration was also measured by specific RIA as reported by Sharp et al. (1977).

\section{Semen quality traits:}

At 14 weeks of age two cockerels from each subgroup were chosen randomly and trained for artificial semen ejaculation by abdominal massage technique (Burrows and Quinn, 1937). All selected cockerels responded similarly and semen evaluation was done at 18 weeks of age as reported by El-Wardany et al. (1995). Semen samples were collected twice a week and immediately examined. The following characteristics were measured for each ejaculate:

1) Volume: Ejaculate volume was measured to the nearest $0.01 \mathrm{ml}$ by using a $10 \mathrm{ml}$ graded tube.

2) Advanced motility: It was estimated by placing a small drop of undiluted semen on a warm slide and examining it immediately under the light objective microscope. The scoring system was from 0 to 5 and based on the percentage of sperms that were in actual progressive motion, where the bottom of the scale 
represents poor motility, the middle of the scale represents average motility and the top of the scale represents excellent motility.

3) The $\mathrm{pH}$ value: initial $\mathrm{pH}$ was obtained by using ( $\mathrm{pH} /$ Temp meter model-671 $\mathrm{p}$ Jenco electronics, LTD, USA)

4) Spermatozoa concentration: It was indirectly calculated according to Taneja and Gowe (1960). From the equation: $\mathrm{H}=0.056+0.422 \mathrm{C}$

Where $\mathrm{H}$ is the spermatozoa concentration in million per $\mathrm{mm}^{3}$ and $\mathrm{C}$ is the packed sperm volume which obtained by centrifuging undiluted semen in haematocrit tubes at speed of (6000 rpm for $10 \mathrm{~min}$ ) using laboratory Haemofuge.

5) The percentage of dead spermatozoa: It was examined by using the nigrosin eosin stain procedure (Hackett and Macpherson, 1965) where one drop from both undiluted semen and warmed stain were placed at the end of a warmed slide, then a thin smear was made by drawing the edge of a second slide across the semen stain mixture. The stained slide was immediately dried and examined microscopically under oil immersion using $100 \mathrm{X}$ objective of the phase contrast microscope. Spermatozoa, either partially or completely stained, were recorded as dead sperm by counting the number of dead sperms that present in 200 spermatozoa in different fields on slide (El-Wardany et al., 1995).

Dead spermatozoa percentage were calculated by the equation:

Dead spermatozoa $\%=$ number of dead sperm $* 100 /$ total counted sperm

6) Abnormalities: the percentage of abnormal sperms was examined by alcohol-eosin stain (5\%) where about 200 sperms per different microscopically fields were counted by using $40 \mathrm{X}$ objective microscope. The abnormal sperms types were head abnormalities (i.e. hooked, tapered, large, double and others), and tail abnormalities (i.e. coiled, broken, tall enlarged, and tailless). The percentage of abnormal sperms was calculated from the following formula:

Abnormal Spermatozoa $\%=$ number of abnormal sperms $* 100 /$ total counted sperms.

\section{Histological observation:}

A representative sample $(0.5 \times 0.5 \mathrm{~cm})$ from the right testis was dissected and fixed in adequate volume of $10 \%$ formalin - saline solution. After dehydration in ascending strength of ethyl alcohol, clearing in benzol and infiltration with paraffin wax; the tissue samples were embedded in paraffin containing paper blocks and then cooled quickly. Thin sections (4-5 micron) were cut, and mounted on glass slides, then stained with the ordinary hematoxylin and eosin stain procedures. Testis sections were examined by using the light microscope to detect their physiological status at different experiment period (El-Wardany and Zein El-Dein, 1995).

\section{Statistical analysis:}

Data were subjected to a two-way analysis of variance with age of injection (T) and the injection dose (R) as main effects using the General Linear Models (GLM) procedure of SAS User's guide (SAS, 2001), according to the model:

$$
Y_{i j k}=\mu+T_{i}+R_{j}+T R_{i j}+f_{i j k}
$$

Where: $Y_{i j k}$ : an observation, $\mu$ : an effect of overall mean, $T_{i} \quad:$ a fixed effect of age of injection, $R_{j} \quad:$ a fixed effect of dose, $T R_{i j}$ : the interaction of $\mathrm{T}$ and $\mathrm{R}$, and $f_{i j k}:$ experimental error, which exp. Error assumed NID $(0, \sigma 2)$

Duncan's multiple range test (Duncan, 1955) was used to separate means when separation was relevant.

\section{RESULTS AND DISCUSSION}

\section{Plasma hormones concentration:}

Table (1) presents the concentrations of LH and FSH of both control and GnRH-treated cockerels at 12 weeks of age, the plasma concentrations of all hormones were insignificant. However LH and testosterone levels in T4 cockerels were higher than the other groups. This increase in both hormones may be due to the role played by LH as a stimulating hormone for leydig cells to synthesis testosterone. 
Table (1): Plasma LH, FSH, and testosterone (Te) concentration (ng/ml) for control and receptaltreated cockerels at 12 wk. of age.

\begin{tabular}{|c|c|c|c|c|c|c|c|c|c|}
\hline \multirow{2}{*}{ Hormone } & \multirow{2}{*}{$\operatorname{Dose}^{1}(\mathrm{R})$} & \multicolumn{4}{|c|}{ Treatment $^{2}(\mathrm{~T})$} & \multirow{2}{*}{ Overall } & \multicolumn{3}{|c|}{ Probability } \\
\hline & & $\mathrm{T} 1$ & $\mathrm{~T} 2$ & $\mathrm{~T} 3$ & $\mathrm{~T} 4$ & & $\mathrm{~T}$ & $\mathrm{R}$ & $\mathrm{T} * \mathrm{R}$ \\
\hline \multirow{3}{*}{$\mathrm{LH}$} & $\mathrm{R} 1$ & $\begin{array}{c}2.63 \\
\pm 0.770\end{array}$ & $\begin{array}{c}1.96 \\
\pm 0.140\end{array}$ & $\begin{array}{c}2.07 \\
\pm 0.230\end{array}$ & $\begin{array}{c}2.63 \\
\pm 0.175\end{array}$ & 2.32 & & & \\
\hline & $\mathrm{R} 2$ & $\begin{array}{c}2.67 \\
\pm 0.770\end{array}$ & $\begin{array}{c}2.16 \\
\pm 0.205\end{array}$ & $\begin{array}{c}2.53 \\
\pm 0.075\end{array}$ & $\begin{array}{c}3.53 \\
\pm 0.125\end{array}$ & 2.72 & & & \\
\hline & Overall & 2.65 & 2.06 & 2.30 & 3.08 & - & NS & NS & $\mathrm{NS}$ \\
\hline \multirow{3}{*}{ FSH } & $\mathrm{R} 1$ & $\begin{array}{c}1.46 \\
\pm 0.840\end{array}$ & $\begin{array}{c}2.06 \\
\pm 0.085\end{array}$ & $\begin{array}{c}2.68 \\
\pm 0.565\end{array}$ & $\begin{array}{c}2.03 \\
\pm 0.170\end{array}$ & 2.06 & & & \\
\hline & $\mathrm{R} 2$ & $\begin{array}{c}1.47 \\
\pm 0.870\end{array}$ & $\begin{array}{c}2.14 \\
\pm 0.260\end{array}$ & $\begin{array}{c}3.05 \\
\pm 0.830\end{array}$ & $\begin{array}{c}3.22 \\
\pm 0.560\end{array}$ & 2.47 & & & \\
\hline & Overall & 1.47 & 2.10 & 2.86 & 2.63 & - & NS & NS & NS \\
\hline \multirow{3}{*}{$\mathrm{Te}$} & $\mathrm{R} 1$ & $\begin{array}{c}2.33 \\
\pm 0.575\end{array}$ & $\begin{array}{c}2.43 \\
\pm 0.055\end{array}$ & $\begin{array}{c}2.34 \\
\pm 0.210\end{array}$ & $\begin{array}{c}2.34 \\
\pm 0.095\end{array}$ & 2.33 & & & \\
\hline & $\mathrm{R} 2$ & $\begin{array}{c}2.34 \\
\pm 0.540\end{array}$ & $\begin{array}{c}2.22 \\
\pm 0.580\end{array}$ & $\begin{array}{c}2.45 \\
\pm 0.695\end{array}$ & $\begin{array}{c}3.29 \\
\pm 0.535\end{array}$ & 2.57 & & & \\
\hline & Overall & 2.33 & 2.32 & 2.39 & 2.76 & - & NS & NS & NS \\
\hline
\end{tabular}

R1:Cockerels were injected by $0.1 \mathrm{ml}$ receptal/kg live body weight, $R 2$ : Cockerels were injected by $0.2 \mathrm{ml}$ receptal kg live body weight weekly.

$T_{1}$ control group injected with saline solution, $T_{2}, T_{3}$, and $T_{4}$ cockerels were weekly injected with Receptal from 6 to10, 8 tol 2 and 10 tol 4 weeks of age respectively.

NS= not significant .

It appears from Table (2) that LH and FSH values of T2 group at 14 weeks of age were lower than that recorded for the other treated or control groups. This could be explained by the inhibitory effect of the higher GnRH level on testicular activity.

Table (2): Plasma LH, FSH, and testosterone (Te) concentration (ng/ml) for control and receptaltreated cockerels at 14 wk. of age.

\begin{tabular}{|c|c|c|c|c|c|c|c|c|c|}
\hline \multirow{2}{*}{ Hormone } & \multirow{2}{*}{$\operatorname{Dose}^{1}(\mathrm{R})$} & \multicolumn{4}{|c|}{ Treatment $^{2}(\mathrm{~T})$} & \multirow{2}{*}{$\begin{array}{c}\text { Overa } \\
l l\end{array}$} & \multicolumn{3}{|c|}{ Probability } \\
\hline & & $\mathrm{T} 1$ & $\mathrm{~T} 2$ & T3 & $\mathrm{T} 4$ & & $\mathrm{~T}$ & $\mathrm{R}$ & $\mathrm{T} * \mathrm{R}$ \\
\hline \multirow{3}{*}{ LH } & $\mathrm{R} 1$ & $\begin{array}{c}3.91 \\
\pm 0.390\end{array}$ & $\begin{array}{c}2.80 \\
\pm 0.540\end{array}$ & $\begin{array}{c}4.22 \\
\pm 0.015\end{array}$ & $\begin{array}{c}4.19 \\
\pm 0.235\end{array}$ & 3.78 & & & \\
\hline & $\mathrm{R} 2$ & $\begin{array}{c}3.90 \\
\pm 0.305\end{array}$ & $\begin{array}{c}2.70 \\
\pm 0.140\end{array}$ & $\begin{array}{c}3.32 \\
\pm 0.500\end{array}$ & $\begin{array}{c}3.68 \\
\pm 0.500\end{array}$ & 3.40 & & & \\
\hline & Overall & $3.90^{\mathrm{a}}$ & $2.75^{\mathrm{b}}$ & $3.77^{\mathrm{a}}$ & $3.93^{\mathrm{a}}$ & - & 0.04 & NS & NS \\
\hline \multirow{3}{*}{ FSH } & $\mathrm{R} 1$ & $\begin{array}{c}2.83 \\
\pm 0.375\end{array}$ & $\begin{array}{c}2.53 \\
\pm 0.890\end{array}$ & $\begin{array}{c}3.34 \\
\pm 0.015\end{array}$ & $\begin{array}{c}4.17 \\
\pm 0.415\end{array}$ & 3.21 & & & \\
\hline & $\mathrm{R} 2$ & $\begin{array}{c}2.86 \\
\pm 0.365\end{array}$ & $\begin{array}{c}2.39 \\
\pm 0.265\end{array}$ & $\begin{array}{c}3.76 \\
\pm 0.500\end{array}$ & $\begin{array}{c}3.33 \\
\pm 0.025\end{array}$ & 3.08 & & & \\
\hline & Overall & $2.84^{\mathrm{ab}}$ & $2.46^{\mathrm{b}}$ & $3.56^{\mathrm{a}}$ & $3.75^{\mathrm{a}}$ & - & 0.06 & NS & NS \\
\hline \multirow{3}{*}{$\mathrm{Te}$} & $\mathrm{R} 1$ & $\begin{array}{c}2.19 \\
\pm 0.410\end{array}$ & $\begin{array}{c}3.15 \\
\pm 0.10\end{array}$ & $\begin{array}{c}3.86 \\
\pm 0.005\end{array}$ & $\begin{array}{c}3.81 \\
\pm 0.125\end{array}$ & $3.25^{\mathrm{a}}$ & & & \\
\hline & $\mathrm{R} 2$ & $\begin{array}{c}2.22 \\
\pm 0.425\end{array}$ & $\begin{array}{c}2.47 \\
\pm 0.285\end{array}$ & $\begin{array}{c}3.59 \\
\pm 0.065\end{array}$ & $\begin{array}{c}3.38 \\
\pm 0.025\end{array}$ & $2.91^{\mathrm{a}}$ & & & \\
\hline & Overall & $2.20^{\mathrm{c}}$ & $2.81^{\mathrm{bc}}$ & $3.72^{\mathrm{a}}$ & $3.59^{\mathrm{ab}}$ & - & 0.01 & NS & NS \\
\hline
\end{tabular}

R1:Cockerels were injected by $0.1 \mathrm{ml}$ receptal/kg live body weight, R2: Cockerels were injected by $0.2 \mathrm{ml}$ receptal /kg live body weight weekly.

$T_{1}$ control group injected with saline solution, $T_{2}, T_{3}$, and $T_{4}$ cockerels were weekly injected with Receptal from 6 tol0, 8 tol 2 and 10 tol 14 weeks of age respectively.

$a, b, c$ Means within treatments and dose with no common superscript differ significantly.

$N S=$ not significant . 
This may reflect the role of appropriate time at which the GnRH injection should be commenced. Earlier injection (from 6 weeks of age T2) seems to be uneffective in stimulating the sporadic release of both LH and FSH from the adenohypophysis. Also, testosterone level shows the same trend as a consequence of the low level of LH. This confirm the results of Chase (1982), El-Wardany et al. (1995) and Vizcarra et al. $(2004,2010,2015)$ who found that LH alone stimulate leydig cells to secret testosterone. The results show also that the effect of treatments was significant in stimulating LH and FSH consequently testosterone secretion. However the dose of injected GnRH was effective for testosterone concentration, with the lower value obtained for the higher dose. At 16 weeks of age, the plasma concentrations of all hormones were comparable to those obtained at 14 weeks of age, which may reflect a type of physiological equilibrium related to the age of sexual maturity. It worse to note that at this age, all cockerels were sexually mature and semen ejaculation procedure was applied to collect semen successfully from them. Results show however, that the T2 cockerels have the lower values of all hormones compared with the other treated cockerels (Table 3).

Table (3): Plasma LH, FSH, and testosterone (Te) concentration (ng/ml) for control and receptaltreated cockerels at 16 wk. of age.

\begin{tabular}{|c|c|c|c|c|c|c|c|c|c|}
\hline \multirow{2}{*}{ Hormone } & \multirow{2}{*}{$\operatorname{Dose}^{1}(\mathrm{R})$} & \multicolumn{4}{|c|}{ Treatment $^{2}(\mathrm{~T})$} & \multirow{2}{*}{ Overall } & \multicolumn{3}{|c|}{ Probability } \\
\hline & & $\mathrm{T} 1$ & $\mathrm{~T} 2$ & $\mathrm{~T} 3$ & $\mathrm{~T} 4$ & & $\mathrm{~T}$ & $\mathrm{R}$ & $\mathrm{T}^{*} \mathrm{R}$ \\
\hline \multirow{3}{*}{$\mathrm{LH}$} & $\mathrm{R} 1$ & $\begin{array}{c}3.05 \\
\pm 0.845\end{array}$ & $\begin{array}{c}2.34 \\
\pm 0.159\end{array}$ & $\begin{array}{c}3.35 \\
\pm 0.125\end{array}$ & $\begin{array}{c}4.54 \\
\pm 0.315\end{array}$ & 3.32 & & & \\
\hline & $\mathrm{R} 2$ & $\begin{array}{c}3.03 \\
\pm 0.870\end{array}$ & $\begin{array}{c}3.01 \\
\pm 0.115\end{array}$ & $\begin{array}{c}3.63 \\
\pm 0.270\end{array}$ & $\begin{array}{c}3.11 \\
\pm 0.675\end{array}$ & 2.94 & & & \\
\hline & Overall & 3.04 & 2.17 & 3.49 & 3.82 & - & NS & NS & NS \\
\hline \multirow{3}{*}{ FSH } & $\mathrm{R} 1$ & $\begin{array}{c}2.35 \\
\pm 0.450\end{array}$ & $\begin{array}{c}2.88 \\
\pm 0.545\end{array}$ & $\begin{array}{c}3.55 \\
\pm 1.370\end{array}$ & $\begin{array}{c}4.56 \\
\pm 0.700\end{array}$ & 3.33 & & & \\
\hline & $\mathrm{R} 2$ & $\begin{array}{c}2.42 \\
\pm 0.480\end{array}$ & $\begin{array}{c}2.10 \\
\pm 0.150\end{array}$ & $\begin{array}{c}3.54 \\
\pm 0.320\end{array}$ & $\begin{array}{c}3.95 \\
\pm 0.945\end{array}$ & 3.00 & & & \\
\hline & Overall & $2.39^{\mathrm{b}}$ & $2.49^{\mathrm{b}}$ & $3.55^{\mathrm{ab}}$ & $4.25^{\mathrm{a}}$ & - & 0.09 & NS & NS \\
\hline \multirow{3}{*}{$\mathrm{Te}$} & $\mathrm{R} 1$ & $\begin{array}{c}3.35 \\
\pm 0.850\end{array}$ & $\begin{array}{c}2.73 \\
\pm 0.115\end{array}$ & $\begin{array}{c}3.59 \\
\pm 1.265\end{array}$ & $\begin{array}{c}3.72 \\
\pm 0.120\end{array}$ & 3.35 & & & \\
\hline & $\mathrm{R} 2$ & $\begin{array}{c}3.32 \\
\pm 0.835\end{array}$ & $\begin{array}{c}2.21 \\
\pm 0.365\end{array}$ & $\begin{array}{c}3.76 \\
\pm 0.090\end{array}$ & $\begin{array}{c}3.03 \\
\pm 0.775\end{array}$ & 3.08 & & & \\
\hline & Overall & 3.33 & 2.47 & 3.67 & 3.37 & - & NS & NS & NS \\
\hline
\end{tabular}

R1:Cockerels were injected by $0.1 \mathrm{ml}$ receptal/kg live body weight, $R 2$ : Cockerels were injected by $0.2 \mathrm{ml}$ receptal /kg live body weight weekly.

$T_{1}$ control group injected with saline solution, $T_{2}, T_{3}$, and $T_{4}$ cockerels were weekly injected with Receptal from 6 to10, 8 tol2 and 10 tol 14 weeks of age respectively.

$a, b, c$ Means within treatments and dose with no common superscript differ significantly.

$N S=$ not significant

\section{Semen quality characteristic:}

The effect of receptal injection on semen volume, advanced motility, semen $\mathrm{pH}$, packed sperm volume (\%) and spermatozoa concentration (million / $\mathrm{ml}$ ) at $18 \mathrm{wk}$. of age are shown in Table (4). Results showed that semen volume was significantly higher in birds that injected at 10 weeks of age $\left(\mathrm{T}_{4}\right)$ at 18 week of age. The birds that injected $0.2 \mathrm{ml} / \mathrm{kg}$ body weight receptal weekly $\left(\mathrm{R}_{2}\right)$ had insignificant higher semen volume than that birds injected $0.1 \mathrm{~m} / \mathrm{kg}$ body weight receptal $\left(\mathrm{R}_{1}\right)$. 
Table (4): Semen quality characteristic at 18 wk. of age for cockerels

\begin{tabular}{|c|c|c|c|c|c|c|c|c|}
\hline \multirow{2}{*}{$\operatorname{Dose}^{1}(\mathrm{R})$} & \multicolumn{4}{|c|}{ Treatment $^{2}(\mathrm{~T})$} & \multirow{2}{*}{ Overall } & \multicolumn{3}{|c|}{ probability } \\
\hline & $\mathrm{T} 1$ & $\mathrm{~T} 2$ & $\mathrm{~T} 3$ & $\mathrm{~T} 4$ & & $\mathrm{~T}$ & $\mathrm{R}$ & $\mathrm{T} * \mathrm{R}$ \\
\hline \multicolumn{9}{|c|}{ Semen Volume (ml) } \\
\hline $\mathrm{R} 1$ & $\begin{array}{c}0.68 \\
\pm 0.025\end{array}$ & $\begin{array}{c}0.80 \\
\pm 0.050\end{array}$ & $\begin{array}{c}0.75 \\
\pm 0.100\end{array}$ & $\begin{array}{c}1.23 \\
\pm 0.125\end{array}$ & 0.86 & & & \\
\hline $\mathrm{R} 2$ & $\begin{array}{c}0.70 \\
\pm 0.050\end{array}$ & $\begin{array}{c}0.73 \\
\pm 0.025\end{array}$ & $\begin{array}{c}1.08 \\
\pm 0.025\end{array}$ & $\begin{array}{c}1.18 \\
\pm 0.125\end{array}$ & 0.92 & & & \\
\hline Overall & $0.69^{\mathrm{b}}$ & $0.76^{\mathrm{b}}$ & $0.91^{\mathrm{b}}$ & $1.2000^{\mathrm{a}}$ & - & 0.001 & NS & NS \\
\hline \multicolumn{9}{|c|}{ Advanced Motility } \\
\hline $\mathrm{R} 1$ & $\begin{array}{c}3.25 \\
\pm 0.250\end{array}$ & $\begin{array}{c}4.0 \\
\pm 0.500\end{array}$ & $\begin{array}{c}4.0 \\
\pm 0.00\end{array}$ & $\begin{array}{c}4.75 \\
\pm 0.250\end{array}$ & 4.0 & & & \\
\hline $\mathrm{R} 2$ & $\begin{array}{c}3.50 \\
\pm 0.500\end{array}$ & $\begin{array}{c}3.75 \\
\pm 0.250\end{array}$ & $\begin{array}{c}3.75 \\
\pm 0.250\end{array}$ & $\begin{array}{c}5.0 \\
\pm 0.00\end{array}$ & 4.0 & & & \\
\hline Overall & $3.38^{\mathrm{b}}$ & $3.88^{\mathrm{b}}$ & $3.88^{\mathrm{b}}$ & $4.88^{\mathrm{a}}$ & - & 0.01 & NS & NS \\
\hline \multicolumn{9}{|c|}{ Semen $\mathrm{pH}$} \\
\hline $\mathrm{R} 1$ & $\begin{array}{c}6.45 \\
\pm 0.080\end{array}$ & $\begin{array}{c}6.51 \\
\pm 0.010\end{array}$ & $\begin{array}{c}6.49 \\
\pm 0.140\end{array}$ & $\begin{array}{c}6.42 \\
\pm 0.025\end{array}$ & 6.47 & & & \\
\hline $\mathrm{R} 2$ & $\begin{array}{c}6.40 \\
\pm 0.030\end{array}$ & $\begin{array}{c}6.48 \\
\pm 0.000\end{array}$ & $\begin{array}{c}6.35 \\
\pm 0.040\end{array}$ & $\begin{array}{c}6.33 \\
\pm 0.045\end{array}$ & 6.39 & & & \\
\hline Overall & 6.43 & 6.50 & 6.42 & 6.37 & - & NS & NS & NS \\
\hline \multicolumn{9}{|c|}{ Packed sperm volume $(\%)$} \\
\hline $\mathrm{R} 1$ & $\begin{array}{c}10.75 \\
\pm 0.770\end{array}$ & $\begin{array}{c}16.91 \\
\pm 0.725\end{array}$ & $\begin{array}{c}22.08 \\
\pm 0.445\end{array}$ & $\begin{array}{c}27.51 \\
\pm 0.810\end{array}$ & 19.31 & & & \\
\hline $\mathrm{R} 2$ & $\begin{array}{c}10.24 \\
\pm 0.270\end{array}$ & $\begin{array}{c}19.26 \\
\pm 0.360\end{array}$ & $\begin{array}{c}22.20 \\
\pm 0.170\end{array}$ & $\begin{array}{c}28.81 \\
\pm 1.395\end{array}$ & 20.13 & & & \\
\hline Overall & $10.50^{\mathrm{d}}$ & $18.08^{c}$ & $22.14^{\mathrm{b}}$ & $28.17^{\mathrm{a}}$ & - & 0.0001 & NS & NS \\
\hline \multicolumn{9}{|c|}{ Spermatozoa concentration ( million $/ \mathrm{ml})^{*}$} \\
\hline $\mathrm{R} 1$ & $\begin{array}{c}4.59 \\
\pm 0.325\end{array}$ & $\begin{array}{c}7.19 \\
\pm 0.305\end{array}$ & $\begin{array}{c}9.37 \\
\pm 0.187\end{array}$ & $\begin{array}{c}11.66 \\
\pm 0.343\end{array}$ & 8.20 & & & \\
\hline $\mathrm{R} 2$ & $\begin{array}{c}4.38 \\
\pm 0.114\end{array}$ & $\begin{array}{c}8.18 \\
\pm 0.153\end{array}$ & $\begin{array}{c}9.42 \\
\pm 0.073\end{array}$ & $\begin{array}{c}12.21 \\
\pm 0.589\end{array}$ & 8.55 & & & \\
\hline Overall & $4.48^{\mathrm{d}}$ & $7.69^{c}$ & $9.40^{\mathrm{b}}$ & $11.94^{\mathrm{a}}$ & - & 0.0001 & NS & NS \\
\hline
\end{tabular}

R1:Cockerels were injected by $0.1 \mathrm{ml}$ receptal/kg live body weight, R2: Cockerels were injected by $0.2 \mathrm{ml}$ receptal $/ \mathrm{kg}$ live body weight weekly.

$T_{1}$ control group injected with saline solution, $T_{2}, T_{3}$, and $T_{4}$ cockerels were weekly injected with Receptal from 6 to10, 8to12 and 10 tol 4 weeks of age respectively.

$a, b, c, d$ Means within treatments and dose with no common superscript differ significantly.

$N S=$ not significant .

The advanced motility of treated birds was significantly higher in treated cockerels (T4) at 18 weeks of age than the other groups. The semen $\mathrm{pH}$ was not significantly affected among treatments; It appears that $\mathrm{GnRH}$ injection is not effective in changing semen $\mathrm{pH}$. Moreover, the results in Table (4) presents the effect of GnRH injection on packed sperm volume (\%) and spermatozoa concentration (million / $\mathrm{ml}$ ) as reported by Taneja and Gowe (1960). There are significant differences in packed sperm volume between treated and non-treated groups at 18 weeks of age, where, T4 and T3 higher and T1 and T2 were lower, respectively. These results clearly indicate the positive effect of the Gonadotropic hormones in the packed sperm volume and hence sperm concentration per ejaculate.

The spermatozoa concentration of treated cockerels was significantly higher than the control group $\left(\mathrm{T}_{1}\right)$. This increase was more obvious as the age of injection initiation increased. It appears also that the dose of GnRH has insignificant effect on spermatozoa concentration at 18 weeks of age. The birds injected $0.2 \mathrm{ml} / \mathrm{kg}$ body weight $\left(\mathrm{R}_{2}\right)$ showed highly insignificant increase in spermatozoa concentration than those injected $0.1 \mathrm{ml} / \mathrm{kg}$ body weight $\left(\mathrm{R}_{1}\right)$.

The effect of receptal injection on abnormal spermatozoa and Dead sperm (\%) are shown in Table (5). Abnormal spermatozoa percentage was significantly reduced in the treated than untreated cockerels at 18 
weeks of age, but the effect of injection dose was not significant. It is of interest to observe that GnRH treatments caused a sharp decrease in the percentage of abnormal sperms in all treated cockerels. Also, the percentage of dead spermatozoa were significantly lower in the treated groups compared by control one.

\section{Dead sperm (\%):}

Dead sperm (\%) was significant decreased in treated cockerels than the control group. Also the effect of injection dose was not significant, but at 18 weeks of age the interaction between injection dose and age of injection initiation showed a significant effect on the percentage of dead spermatozoa.

Table (5): Abnormal and dead spermatozoa (\%) at 18 wk. of age for cockerels.

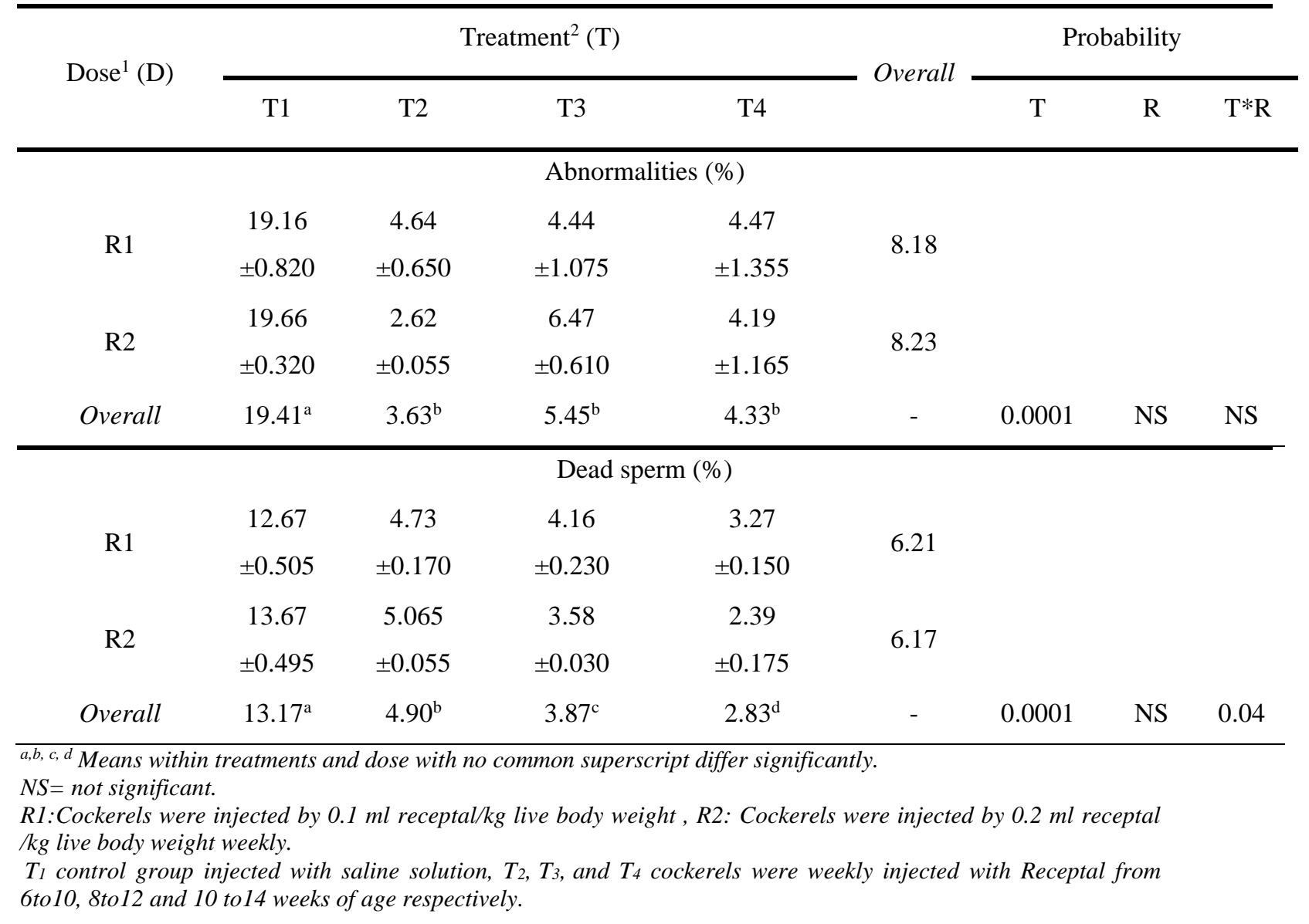

It is likely that GnRH injection improved nearly all the semen quality traits. However, the significant positive results were recorded for semen volume, advanced motility, concentration, abnormal and dead sperm percentages. This effect was found to be related to the age at which the injection is commenced and to the dose injected GnRH. This may support the hypothesis that the spermatogenic activity is under the control of the hypothalamic releasing hormones in the specific level of the injected hormone(s). In agreement with the present results many authors reported that GnRH injection promote gonadal maturation in different mammalian and avian species and stimulates the spermatogenesis process (Katz et al., 1990, Sharp et al., 1994, Maraie et al., 1998, and Fathi et al., 2000, Kuenzel, 2000 and El- Nagar 2009). That the exogenous GnRH enhanced semen quality traits was also supported by the findings of Fathi et al. (2000) who obtained an excellent results from naked neck cocks with previously known low fertilizing capacity and low semen quality traits. It should be borne in mind that the exogenous GnRH treatment may exert a favorable effect on the spermatogenic activity of the testicular tissues which in turn enhance the quality of semen as recorded in the present study. The best results were obtained however when GnRH injection is initiated at 8 or 10 weeks of age (T3 and T4) for higher semen volume, spermatozoa concentration and at 6,8 and (or) 10 weeks of age for lower abnormal and deed spermatozoa. 


\section{Histological changes of the testicular tissues:}

Histological examination of the testis section after GnRH injection for different groups of Gimmizah cockerels are presented in Figures (1 and 2). At 12 weeks of age (Figure 1), the seminiferous tubules of the untreated (control) males were large, their laminae were wide and filled with spermatids and few spermatozoa (Fig. 1 A). However in the T2 treatment (injected from 6 to $10 \mathrm{wk}$ ), the results clearly show irregular distribution of the spermatogenic cells which may be due to the higher concentration of exogenous GnRH. This may cause an increase in mitotic and meiotic divisions of the epithelium.

The effect was more obvious in Fig. 1 B r1 than B r2. More, leydig cells are presented as a result of GnRH injection, which may suggest a higher LH concentration. When cockerels were injected from 8 weeks of age (T3) an enhanced spermatogenic activity was obtained, especially with the higher dose (Fig. $1 \mathrm{C} \mathrm{r} 2)$ compared with the $(\mathrm{C} \mathrm{r} 1)$ or the other treatments. There are numerous spermatozoa, spermatids and sertoli cells in the cross section of testis from T3- cockerels. Similar observations are noticed in T4 cockerels which were injected from 10 weeks of age. It is likely that, all cockerels are able to produce semen at this age. However, no attempts were done to collect semen at this time. The abdominal massage technique was used from 14 weeks of age. At this age, testis sections from all treated and untreated males showed similar stages and arrangement of different cell types occurred during spermatocytogenesis (Figure $2 \mathrm{~A}$ to D). However, the treated groups showed higher degrees of spermatogenic activities and more leydig cells encapsulated in distinct areas of all section. It is well known that the spermatocytogenesis process in mammals and birds is LH and FSH dependent (Aire at al., 1980; Tanaka and Yasuda 1980; Wilson et al., 1988; El-Wardany and Zein El-Dein (1995) and Thurston and Korn, 2000). The enhancing role of these hormones on spermatogenesis is mainly through testosterone secretion from leydig cells (Sharp and Gow, 1983 and Deviche et al., 2011).

Since it appears from the present results that GnRH injection at 6 weeks of age was not effective in stimulating normal spermatogenic activity, although some histological changes are detected. Consequently, initiation of injection from 8 weeks of age was shown to give the best results concerning histological appearance of testis with the higher dose of GnRH being the best for all treatments. These results confirm the previous findings the hypothalamus-pituitary-testis axis are very important in regulating the spermatogenic cycle of males birds, and this effect could be obtained by exogenous GnRH injection at considerable age(s) before sexual maturity (Sturkie, 1986; Onuora, 1987; Sullivan and Silverman, 1993; and Scanes, 2000).

\section{CONCLUSION}

It could be concluded from the present findings that, the precocious puberty in cockerels could be achieved by GnRH injection. However, Receptal injection enhances semen quality traits, increased spermatogenic activity and testis histology. It is recommended to use GnRH (Receptal) injection from 8 or 10 weeks of age for better productivity. 


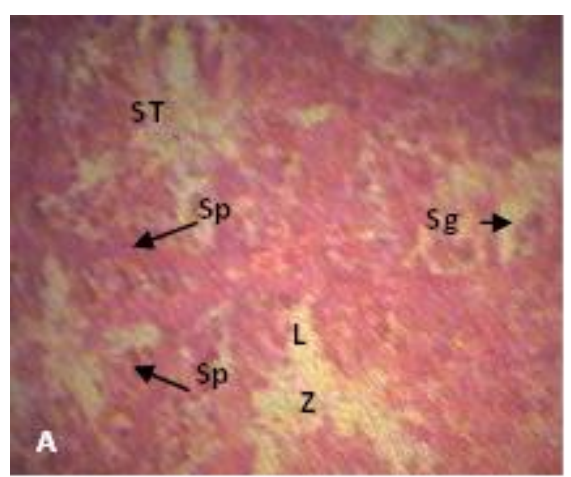

A: Control (T1): A multilayer spermatogenic cells representing different stages of spermatogenesis (arrows).
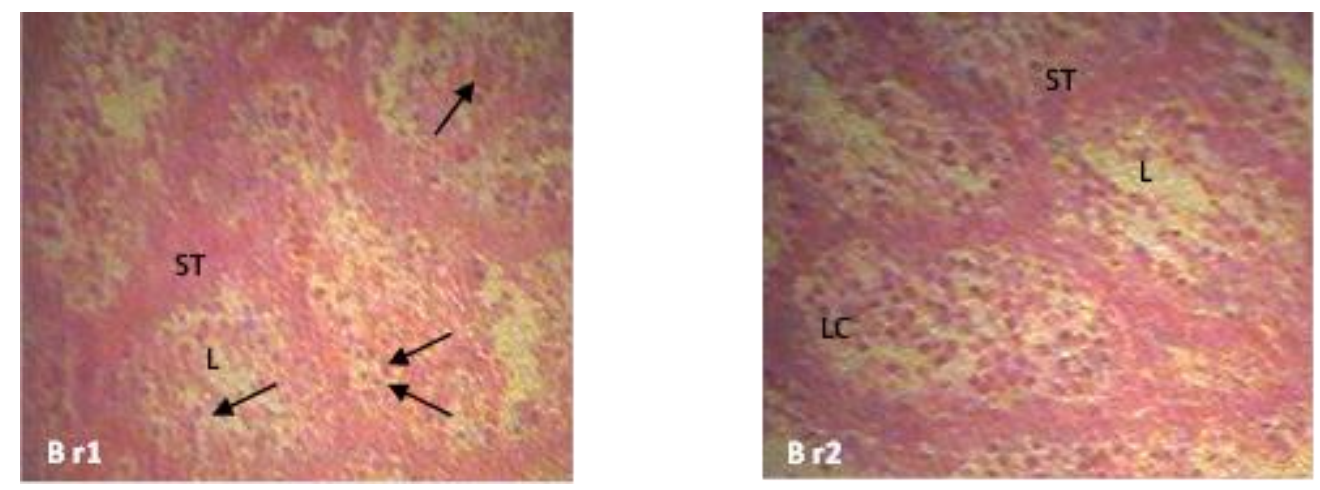

B: T2: Two weeks after the end of treatment. The arrangement of cells is disturbed. All stages of spermatogenic cells are present (arrow). More leydig cells are present (LC).
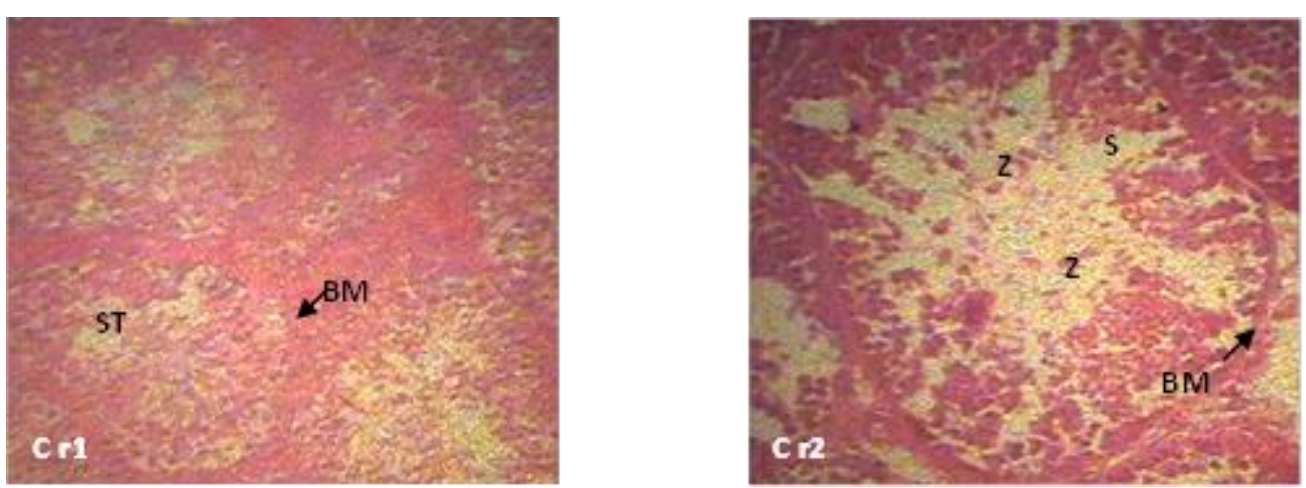

C: T3: An increase in germinal epithelium activity in $\mathrm{Cr} 1$ with a small tubular lumen. All stages of spermatogenesis are present from spermatogonia $(\mathrm{Sg})$ to spermatozoa (Z). Sertoli cells are also observed, and the tubular diameter is greater in $\mathrm{Cr} 2$. 


\section{Abdo et al.}
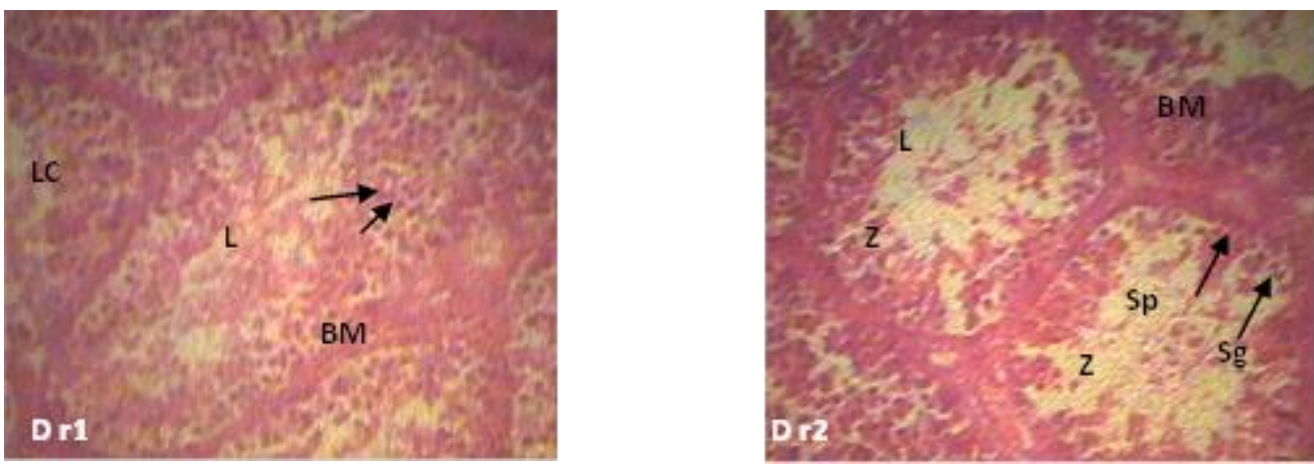

D: T4: Two weeks after GnRH-treatment, causes an increase in the spermatogenic activity (arrows) and the lumen diameter is greater (L) with a well defined basement membrane in (Dr1). Many spermatozoa ( $\mathrm{Z}$ ) and spermatids (Sp) are present with a moderate increase in the tubular lumen (in Dr2).

Figure (1): Cross section of the testis from the control and GnRH-treated cockerels at 12 weeks of age $(H \& E \times 200)$.

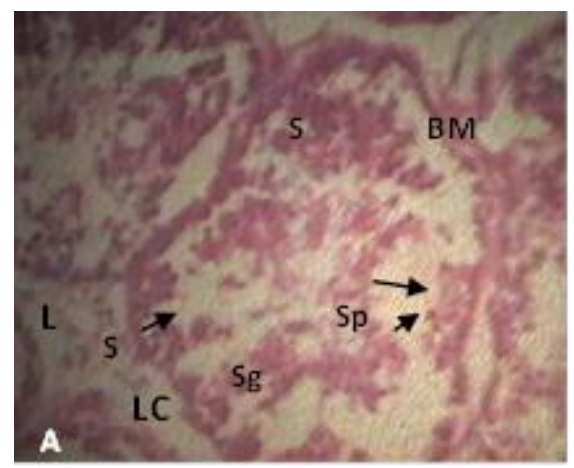

A: Control (T1): More mature cells with enlarged seminiferous tubules showing different stages of spermatogenesis.
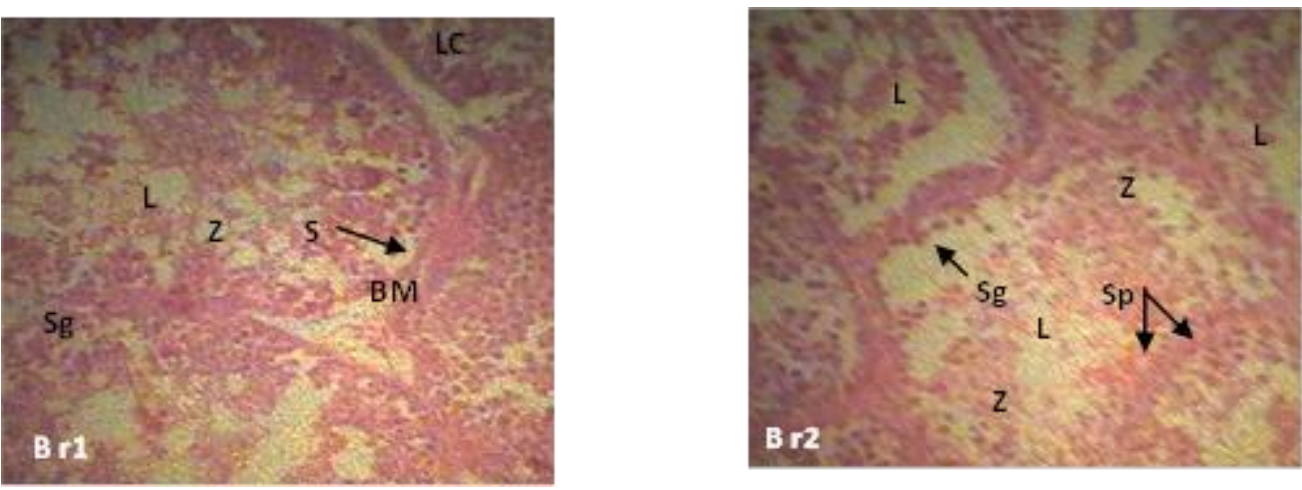

B: T2: A very active spermatogenesis showing regular arrangement of all cells from spermatogonia to spermatozoa in both $\mathrm{Br} 1$ and $\mathrm{Br}$. More mature spermatozoa are present in $\mathrm{Br} 2$ (around L). 

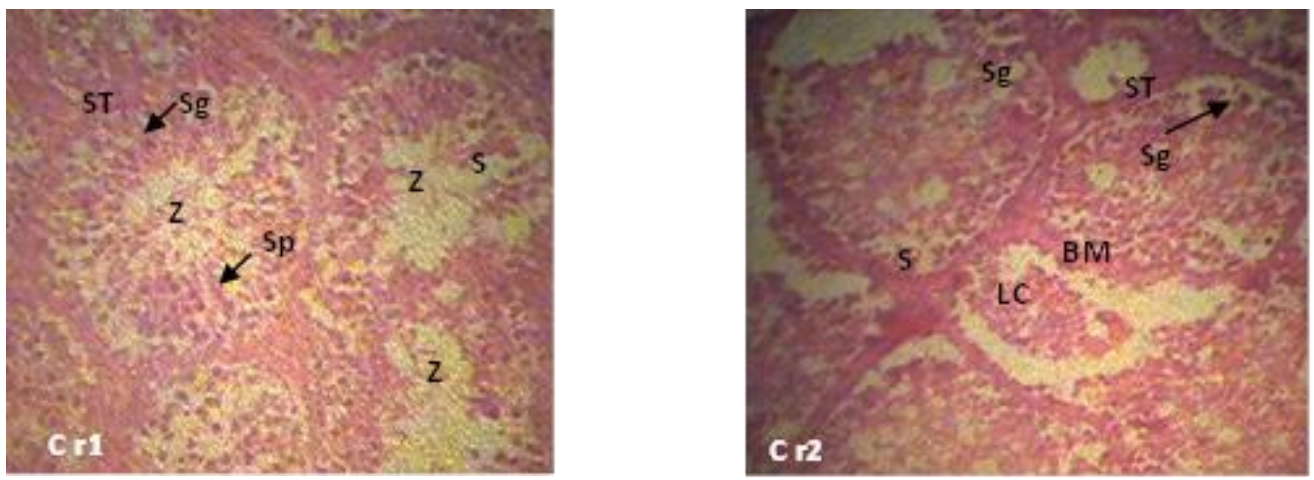

C: T3: Numerous spermatozoa in the ST lumen in Cr1. Higher spermatogenic activity in $\mathrm{Cr} 2$.
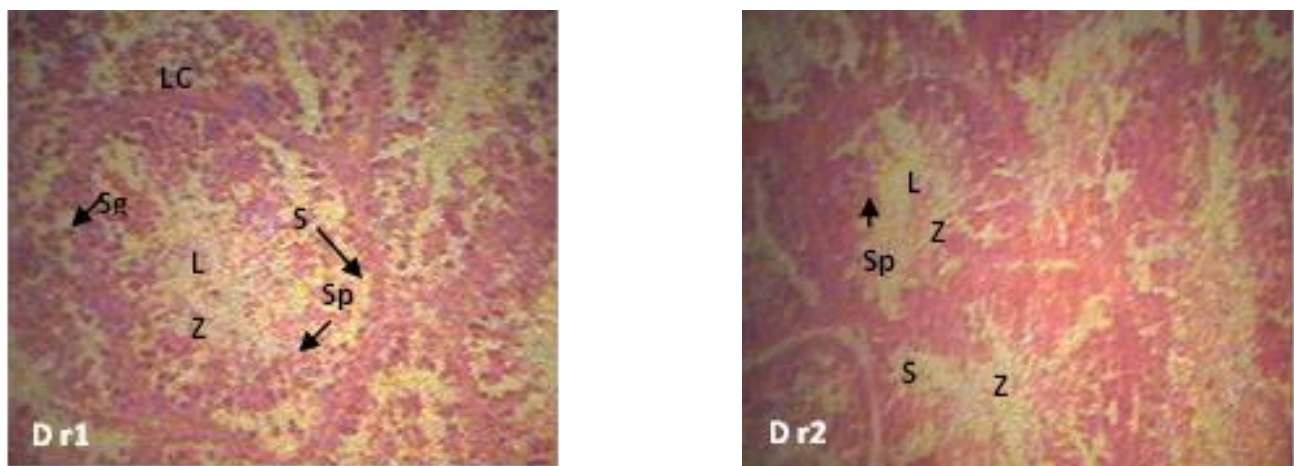

D: T4: Four weeks of GnRH injection (from 10 to 14 weeks of age) indicates higher spermatogenic activity and rapid spermatozoa outflow from the ST lumen in both Dr1 and Dr2.

Figure (2): Cross section of the testis from the control and GnRH-treated cockerels at 14 weeks of age $(\mathrm{H} \& \mathrm{E} \times 200)$.

\section{REFERENCES}

Aire, T.; M. Okorun and J. Ayeni (1980). The seminiferous epithelium in the guinea fowl. Cell Tissue Res., 205: 319-325.

Burrows, W. H and J. P. Quinn (1937). The collection of spermatozoa from the domestic fowl and turkey. Poult. Sci., 16: 19-24.

Chase, D. J. (1982). Gonadotropin specificity of acute testicular androgen secretion in birds. Cen. Com. Endocrinol., 46: 486-492.

Deviche, P.; L. L. Hurley and H. B. Fokidis (2011). Avian Testicular Structure, Function, and Regulation. Hormones and Reproduction of Vertebrates, Volume 4- Birds: 27-70.

Duncan, D.B. (1955). Multiple range and multiple "F" test. Biometrics, 11: 1-42.

El- Nagar, S. A. (2009). Response of Alexandria cockerels reproductive status tp GnRH (Reseptal) injection. Inter. J. Poult. Sci., 8: 242- 246.

El-Wardany, I. and A. Zein El-Dein (1995). Testis histology and semen quality of naked neck cockerels as affected by vitamin E and selenium supplementation. J. Agric. Sci. Mansoura Univ., 20 (6): 28532861. 
El-Wardany, I.; A. Zein El-Dein and S. H. Hassanin (1995). Evaluation of semen quality traits to predict the fertility potemtial of males from three strains of chickens. J. Agric. Sci. Mansoura Univ., 20 (3): 1071- 1084.

Fathi, M. M; E. E. Tharwat and Y. M. EL-Hommosany (2000). Response of semen quality of Naked neck cocks to zinc supplementation or GnRH injection. Egypt. Poult. Sci., 20: 1047-1064.

Follett, B. K.; C. G. Scanes and F. J. Cunningham (1972). A radioimmunoassay for avian luteinizing hormone. Endocrinol., 52: 359-378.

Hackett, A. J. and J. W. McPherson (1965). Some staining procedures for spermatozoa. Canadian Veterinary Journal, (A Review) 6: 55-62.

Hezarjaribi, A; V. Rezaeipour and R. Abdollahpour (2016). Effects of intramuscular injections of vitamin E-selenium and a gonadotropin releasing hormone analogue ( $\mathrm{GnRHa}$ ) on reproductive performance and blood metabolites of post-molt male broiler breeders. Asian Pacific Journal of Reproduction, 5:156- 160 .

Katz, I. A; R. P. Millar and J. P. King (1990). Differential distribution and release of two forms of gonadotropins releasing hormone in the chicken brain. Peptides, 11: 443-450.

Kozdera, A; K. Veznik and L.Rysava (1993). Average testosterone levels in bulls after GnRH stimulation at breeder bull rearing station and A.I. station. Vet. Medicina, 38(3): 129-140.

Krishnan, K. A.; J. A. Proudman; D. J. Blot and J. M. Bolir (1993). Development of an homologous radioimmunoassay for chicken follicle stimulating hormone and measurement of plasma FSH during the ovulatory cycle. Comp. Physiol., 105A: 729-734.

Kuenzel, W. J. (2000). Central nervous system regulation of gonadal development in the avian male. Poult. Sci., 79: 1679-1688.

Marai, I. F. M; M. A. A. EL-Kariem; A. E. B. Zeidan; T. S. T. Selem and A. M. Abd-EL-Kareim (1998). Reproductive performance of heat stressed low fertile male rabbits as affected by types of GnRH injection. First International Conference on Animal Production and Health in Semi-Arid Areas. ELArish, Egypt, PP.423-431.

Mahmoud, T. H; I. F. Sayed; Y. H. Madkour and M. M. Honein (1982). The Gimmizah a new breed of chicken. Agric. Res. Rev., Cairo, 60: 51-67.

Onuora, G. I. (1987). Spermatogenic activities of the left and right testes of hemicastrated and intact cockerels. Anim. Reprod. Sci., 14: 157-164.

SAS ( 2001). SAS/STAT® User's Guide. Version 8.2, SAS Institute, Cary, NC., USA.

Scanes, C. G. (2000). Introduction to endocrinology: Pituitary gland. Chap. 26: 437-460. in Sturkie's Avian Physiology $5^{\text {th }}$ ed. G. C. Whittow, Academic Press, New York, NY.

Sharp, P. J; J. Culbert and J. W. Wells (1977). Variation in stored and plasma concentrations of androgen and luteinizing hormone during sexual development in the cockerels. J. Endocrinol., 74: 467-476.

Sharp, P. J. and C.B. Gow (1983). Neuroendocrine control of reproduction in the cockerel. Poult. Sci., 62 : 1671-1675.

Sharp, P. J., R. T. Talbot; G. M. Main; I. C. Dunn; H. M. Fraser and N. S. Huskisson (1994). Physiological role of chicken LHRH-I and -II in the control of gonadotrophin release in the domestic chicken. J. Endocrinol., 124: 291-299.

Stevenson, J. S; K. D. Ffrantz and E. P. Call (1988). Conception rates in repeat breeder and dairy cattle with unobserved estrus after prostaglandin F2 alpha and gonadotropin releasing hormone. Theriogenology, 29(2): 451-460.

Sturkie, P. D. (1986). Avian physiology, $4^{\text {th }}$ Ed. Springer Virlog. N. Y. Heidelberg, Berlin.

Sullivan, K. A. and A-J Silverman (1993). The ontogeny of gonadotropin-releasing hormone neurons in the chick. Neuroendocrinol. 58: 597-608.

Tanaka, S. and M. Yasuda (1980). Histological changes in the testis of domestic fowl after adenohypophsectomy. Poult. Sci., 59: 1538-1545. 
Taneja, G.C. and R.S. Gowe (1960). Spermatozoa concentration in the semen of two breeds of fowl estimated by three different methods, Poult. Sci., 40: 608-615.

Thurston, R. J. and N. Korn (2000). Spermiogenesis in commercial poultry species: anatomy and control. Poult. Sci., 79: 1650-1668.

Vizcarra, J.; R. Alan and J. Kirby (2015). Reproduction in male birds. In: Scanes CG (Ed.). Sturkie's avian physiology. 6th ed. San Diego, CA: Academic Press, p.667-693.

Vizcarra, J.A.; J.D. Kirby and D.L. Kreider (2010). Testis development and gonadotropin secretion in broiler breeder males. Poult. Sci., 89:328-334.

Vizcarra, J.A.; D.L. Kreider and J.D. Kirby (2004). Episodic gonadotropin secretion in the mature fowl: serial blood sampling from unrestrained male broiler breeders (Gallus domesticus). Biol Reprod, 70:1798-1805.

Weil, S; I. Rozenboim, A. A. Degen, A. Dawson, M. Friedlander and A. Rosenstrauch (1999). Fertility decline in aging roosters is related to increased testicular and plasma levels of estradiol. Gen. and Comp. Endocrinol., 115(1): 23-28.

Wilson, J. L; L. M. Krista; G. R. Mc Daniel and C. D. Sutton (1988). Correlation of broiler breeder male semen production and testes morphology. Poult. Sci., 67(4):660-668.

الاستجابة الفسيولوجية والهستولوجية للحقن بال-GnRH في ديوك الجميزة

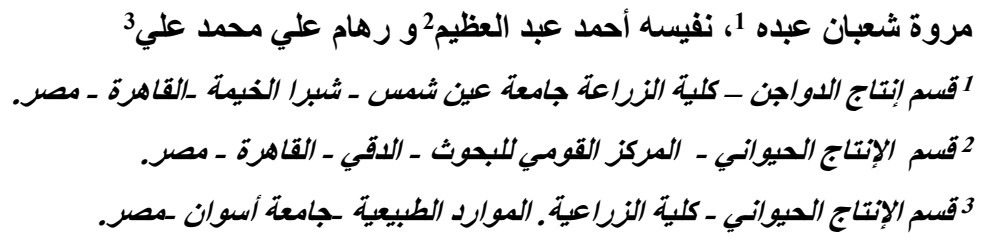

أجريت هذه الدراسة لدراسة التحكم العصبى الهرموني في تكوين الحيوانات المنوية لاجاج سلالة الجميزة. تم اختيار 300 كتيكوت

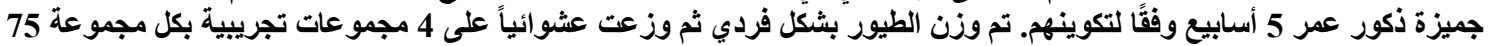

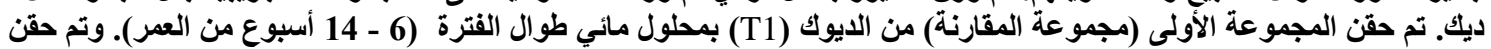

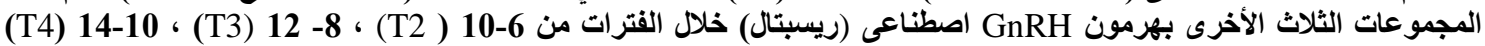

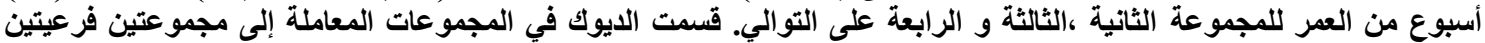

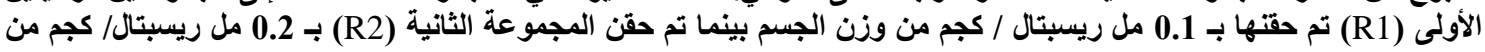
وزن الجسم.

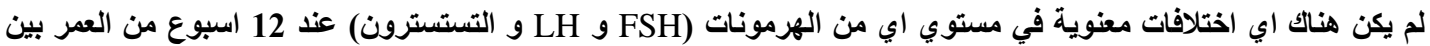

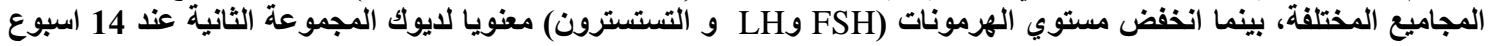

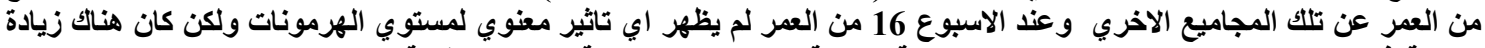

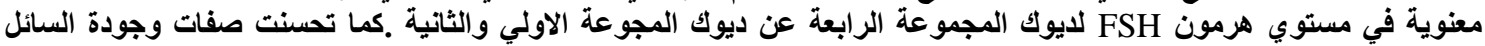

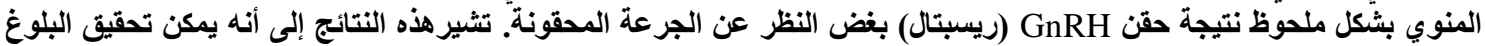

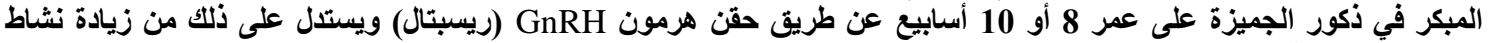
الحيوانات المنوية فى هذا العمر مع حقن عمر الريسبتال. 